\title{
Sediment budget in the Ucayali River basin, an Andean tributary of the Amazon River
}

\author{
WILLIAM SANTINI ${ }^{1,2}$, JEAN-MICHEL MARTINEZ ${ }^{1,2}$, RAUL ESPINOZA- \\ VILLAR $^{3}$, GERARD COCHONNEAU ${ }^{1,2}$, PHILIPPE VAUCHEL ${ }^{1,2}$, \\ JEAN-SEBASTIEN MOQUET ${ }^{4}$, PATRICE BABY ${ }^{1,2}$, JHAN-CARLO ESPINOZA ${ }^{5}$, \\ WALDO LAVADO ${ }^{6}$, JORGE CARRANZA ${ }^{6}$ \& JEAN-LOUP GUYOT ${ }^{1,2}$ \\ 1 IRD (Institut de Recherche pour le Développement) \\ william.santini@ird.fr \\ 2 GET (Géosciences Environnement Toulouse), Casilla 18-1209, Lima 18, Peru \\ 3 UnB-IG (Universidade de Brasilia- Instituto de Geociencias), Campus Universitário Darcy Ribeiro, Brasilia, Brazil \\ 4 USP (Universidade de São Paulo), Av. Prof. Almeida Prado, $n^{\circ} 1280$ - Butantã, São Paulo, Brazil \\ 5 IGP (Instituto Geofisíco del Perú), Calle Badajoz \#169 - Mayorazgo IV Etapa - Ate Vitarte, Lima, Peru \\ 6 SENAMHI (Servicio Nacional de Meteorología e Hidrología), Casilla 11-1308, Lima 11, Peru
}

\begin{abstract}
Formation of mountain ranges results from complex coupling between lithospheric deformation, mechanisms linked to subduction and surface processes: weathering, erosion, and climate. Today, erosion of the eastern Andean cordillera and sub-Andean foothills supplies over $99 \%$ of the sediment load passing through the Amazon Basin. Denudation rates in the upper Ucayali basin are rapid, favoured by a marked seasonality in this region and extreme precipitation cells above sedimentary strata, uplifted during Neogene times by a still active sub-Andean tectonic thrust. Around $40 \%$ of those sediments are trapped in the Ucayali retro-foreland basin system. Recent advances in remote sensing for Amazonian large rivers now allow us to complete the ground hydrological data. In this work, we propose a first estimation of the erosion and sedimentation budget of the Ucayali River catchment, based on spatial and conventional HYBAM Observatory network.
\end{abstract}

Key words Ucayali; Pachitea; Andes; Amazon; erosion; sedimentation; MODIS; Peru; hydrology

\section{INTRODUCTION}

The Ucayali River is a main Andean tributary of the Amazon River, the largest river system in the world. It drains a large region, from the Nevado Mismi (5597 m a.s.l.), recognized today as the source of the Amazon River, to its confluence with the Marañón river ( $\sim 90 \mathrm{~m}$ a.s.l.), near Iquitos. A large part of its drainage area is Andean ( $\sim 56 \%$, considering the Andean domain limit at $500 \mathrm{~m}$ a.s.1.). The Ucayali River basin is of great economic interest for Peru, as it hosts large reserves of gas, supports fluvial transportation of goods and people, tourism and wood commerce. Consequently, the basin is facing recent transformations and increasing anthropogenic pressure.

Since 2003, the work of the HYBAM program (Geodynamical, hydrological and biogeochemical control of erosion/alteration and material transport in the Amazon basin; www.ore-hybam.org) have allowed quantification of discharges, sediment loads and geochemical fluxes from major Amazonian tributaries with accuracy, precision and over a long period. The first ever suspended sediment yields (SSY) and budgets estimates for the Peruvian Amazon were published by the HYBAM program, showing stable balances from upstream to downstream (Guyot et al., 2007, Armijos et al., 2013). However, these studies did not address erosion and sedimentation processes in the foreland basins. The sedimentary contributions from Andean tributaries and re-suspension processes could mask a very strong sedimentation in subsidence zones localized between the control points of the HYBAM's network. Also, the spatial distribution of SSY into the Peruvian Amazon-Andean basin is poorly documented. In this work, we thus propose an assessment of the sediment budget of the Ucayali River using ground and remotesensing data for the 2009-2012 hydrological cycles. Indeed, the development of remote sensing techniques such as the continental altimetry and water colour monitoring with MODIS images today allow us to complement conventional hydrologic network data (Calmant et al., 2008; Martinez et al., 2009, Espinoza-Villar et al., 2012). 
Table 1 Characteristics of river gauge stations in Ucayali River basin.

\begin{tabular}{lllrrrrrrrr}
\hline $\begin{array}{l}\text { Station } \\
\text { Code }\end{array}$ & $\begin{array}{l}\text { Gauging } \\
\text { Station }\end{array}$ & River & $\begin{array}{l}\text { Alt. } \\
(\mathrm{m})\end{array}$ & \multicolumn{1}{c}{$\begin{array}{l}\text { Lat. } \\
(\mathrm{deg})\end{array}$} & $\begin{array}{l}\text { Long. } \\
(\mathrm{deg})\end{array}$ & $\begin{array}{l}\text { Total area } \\
\left(\mathrm{km}^{2}\right)\end{array}$ & $\begin{array}{l}\text { Andean } \\
\text { area }\left(\mathrm{km}^{2}\right)\end{array}$ & $\begin{array}{c}\text { (\%) } \\
\text { Lean discharge } \\
\left(\mathrm{m}^{3} \mathrm{~s}^{-1}\right)\end{array}$ & $\left(\mathrm{L} \mathrm{s}^{-1} \mathrm{~km}^{-2}\right)$ \\
\hline LAG & Lagarto & Ucayali & 195 & -10.61 & -73.87 & 191180 & 165760 & 87 & 7160 & 37 \\
PIN & Puerto Inca & Pachitea & 190 & -9.38 & -74.96 & 22300 & 16100 & 56 & 2380 & 107 \\
PUC & Pucallpa & Ucayali & 145 & -8.38 & -74.53 & 261070 & 186200 & 71 & 9720 & 37 \\
REQ & Requena & Ucayali & 95 & -5.03 & -73.83 & 347990 & 193400 & 56 & 10740 & 31 \\
\hline
\end{tabular}

\section{THE UCAYALI RIVER BASIN}

The Ucayali River basin stretches for $\sim 350500 \mathrm{~km}^{2}$ between $15.5^{\circ} \mathrm{S}$ to $4.7^{\circ} \mathrm{S}$. It may be divided roughly into four parts: An Andean domain lined by the Eastern Cordillera with steep slopes and its adjacent sub-Andean fold and thrust belt. These latter zones are formed by sedimentary strata (mainly Palaeozoic) (Dumont et al., 1991; Espurt et al., 2008), and igneous rocks outcropping on several domes. From $10.7^{\circ} \mathrm{S}$ to $8.9^{\circ} \mathrm{S}$, the Ucayali River flows through a wide monocline between the Shira Mountains and the Fitzcarrald Arch (Fig. 1). In this stretch, the morphology of the river changes from anastomosed to meandered, as a result of decreasing slope. This area is hydraulically controlled by the tectonic load of the Shira Mountains thrust system, as shown in Fig. 1(b). Between

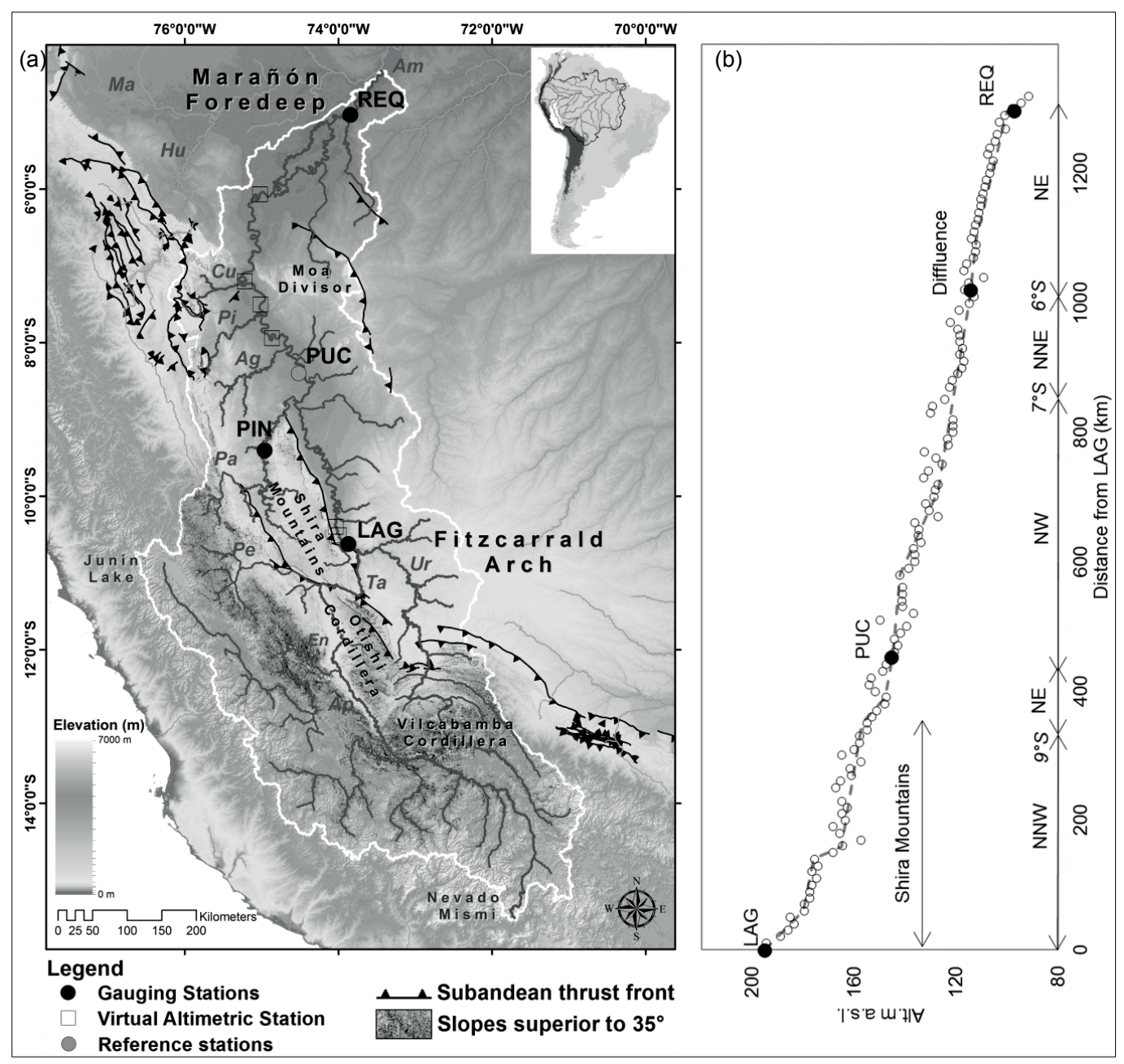

Fig. 1 (a) Location of the gauging stations in the Ucayali basin; relief data from SRTM (see Table 1 for station codes). Am, Amazon River; Ma, Marañón River, Hu, Huallaga River ; Cu, Cushabatay River ; Pi, Pisqui River; Ag, Aguaytia River; Pa, Pachitea River; Pe, Perene River; En, Ene River; Ap, Apurimac River; Ta, Tambo River; Ur, Urubamba River. (b) Slope between LAG and REQ extracted from SRTM. Direction of the main stream is indicated in the X axis. 
PUC station and Contamana city $\left(7^{\circ} \mathrm{S}\right)$, the Ucayali River meanders towards the NNW between the Sub-Andean foothills and the Moa Divisor, over a vast flood plain sprinkled with oxbow lakes. North of the Cushabatay massif and Contamana arch, the river dives into the Marañon foredeep (at $8^{\circ} \mathrm{S}$ ), changing its course from NNW to $\mathrm{NE}$, bringing about a river bifurcation on a part of the reach.

Mean annual rainfall over the western Amazon region shows a latitudinal gradient with abundant rainfall in the northern lowlands, which diminishes southward and over the mountains (Espinoza et al., 2009). Strong spatial variability in rainfall is observed on the eastern flank of the Andes. At the seasonal time-scale, upper Ucayali basin is characterized by a marked dry season during the austral winter and wet season during the austral summer. At the inter-annual time-scale, several studies describe that a significant fraction of rainfall variability in the southern AndesAmazon region is related to the El Niño Southern Oscillation (Garreaud et al., 2008). In general El Niño years tend to be dry, while La Niña years are often associated with wet conditions and floods (Espinoza et al., 2013; Lavado et al., 2013). One of the major extreme precipitation cells known in the Eastern cordillera is located above the Pachitea basin (Pa in Fig. 1(a)).

\section{DATA AND METHODS}

Both conventional hydrological data and remote-sensing methods used here were acquired within the framework of the HYBAM program. Water levels, discharges and Suspended Sediment Concentrations (SSC) data were processed using Hydracess software (Vauchel, 2007) for standard hydrologic treatments and data analysis. Hydromesad allows us to combine discharge acquisition from Acoustic Doppler Current Profiler (ADCP) with SSC data. VALS software was used for remote-sensing altimetry data processing. Finally, GetModis and Mod3R allowed extraction of remote sensing reflectance from MODIS images (Cochonneau, 2009). All these software can be downloaded at http://www.ore-hybam.org/index.php/eng/Software.

In this work we used four conventional stations (LAG, PUC, REQ, PIN), six altimetric stations and three river masks defined for the assessment of MODIS reflectance at LAG, PUC and REQ (see Fig. 1). At conventional stations, water levels were read twice a day by observers. SSC were sampled at three stations, LAG, REQ, and more recently PIN, in the centre reach of a river with a sampling protocol taking into account temporal SSC variability. Several times a year, at low, medium and high water, HYBAM staff conducted field measurements using the same protocol over the three stations for suspended sediment and water discharge assessment (Filizola \& Guyot, 2004). River discharges were measured with ADCP, coupled with a GPS for a correction of moving bottom errors. To take into account the spatial variability of SSC over large river crosssections, 9 to 15 point samples were taken, distributed on three verticals. At the measurement time, 3 to 5 samples were taken at the same location as where the observer usually sampled. In this way, we were able to fit a rating curve between the Surface SSC from the observer and the cross-section Average SSC from the measurement. Using this data, Suspended Sediment Loads (SSL) were calculated using HYBAM software: Surface SSC were converted into Average SSC with the fitted rating curve, and the averaging method $(\mathrm{SSL}=\mathrm{Q} \times \mathrm{SSC})$ was used to calculate SSL, interpolating SSC when necessary. At PIN, as the period of sampling was reduced, we chose to fit a powerrating curve with parametric bootstrap method to assess the river sediment fluxes from the water discharge. At PUC, we built SSC series extracted from MODIS images using fitted relations between infrared reflectance and SSC at LAG and REQ. Consequently, we used framed SSC values at PUC (low values corresponding to REQ trend and high values to LAG trend) to calculate framed SSL values. We assessed sedimentary production of the Cushabatay River, Pisqui River and Aguaytia River sub-basin by a regionalization method based on their Andean basin area. Based on the low SSY of the Orthon River compared to the high Andean production rates, we neglected the Fitzcarrald Arch contributions to the sediment budget. The whole water level dataset from the gauging stations has been screened and completed whenever needed by estimation through correlative methods and with continental altimetry techniques. Due to different periods of data acquisition, we chose a common period from September 2009 to August 2012. 


\section{RESULTS AND DISCUSSION}

Hydrographs presented in Fig. 2(a) show important water storage in the flood plain from November to March ( $\sim 11 \%$ of the total volume of water discharged from the Ucayali River into the Amazon River). From April to August, the water stored flows back to the river main stream and adds to small contributions coming from northern Ucayali basin, where rainfall seasonality is less marked due to the South America monsoon regime. This seasonal process probably induces sediment re-suspension and bank erosion in the flood plain between May and August, as highlighted in Fig. 2(a). This effect is clearly visible on the relationships linking SSL and discharge at the monthly time-step, showing hourly hysteresis at PUC and REQ. We consider that sediment re-suspension may represent $13 \%$ of Ucayali River SSL budget.

Table 2 Suspended sediment data for the Ucayali River in the period 2009-2012.

\begin{tabular}{|c|c|c|c|c|}
\hline Station code & River & $\begin{array}{l}\text { Suspended sediment } \\
\text { Avg. SSC (mg L-1) } \\
\text { Max-min (Avg.) }\end{array}$ & $\begin{array}{l}\text { SSL (Mt year-1) } \\
\text { Max-min (Avg.) }\end{array}$ & $\begin{array}{l}\text { SSY }\left(\mathrm{t} \mathrm{km}^{-2} \text { year }^{-1}\right) \\
\text { (Andean catchment) }\end{array}$ \\
\hline LAG & Ucayali & 1260 & 445 & 2680 \\
\hline PIN & Pachitea & 750 & 60 & 4020 \\
\hline PUC & Ucayali & $950-630(790)$ & $360-235(300)$ & \\
\hline Lateral tributaries & $\mathrm{Ag}+\mathrm{Pi}+\mathrm{Cu}$ & & 20 & 2700 \\
\hline REQ & Ucayali & 790 & 305 & \\
\hline Total Andean erosion & & & 525 & 2710 \\
\hline$(\mathrm{LAG}+\mathrm{PIN})-\mathrm{PUC}$ & & & $140-270(205)$ & \\
\hline Total sedimentation & & & 220 & \\
\hline
\end{tabular}
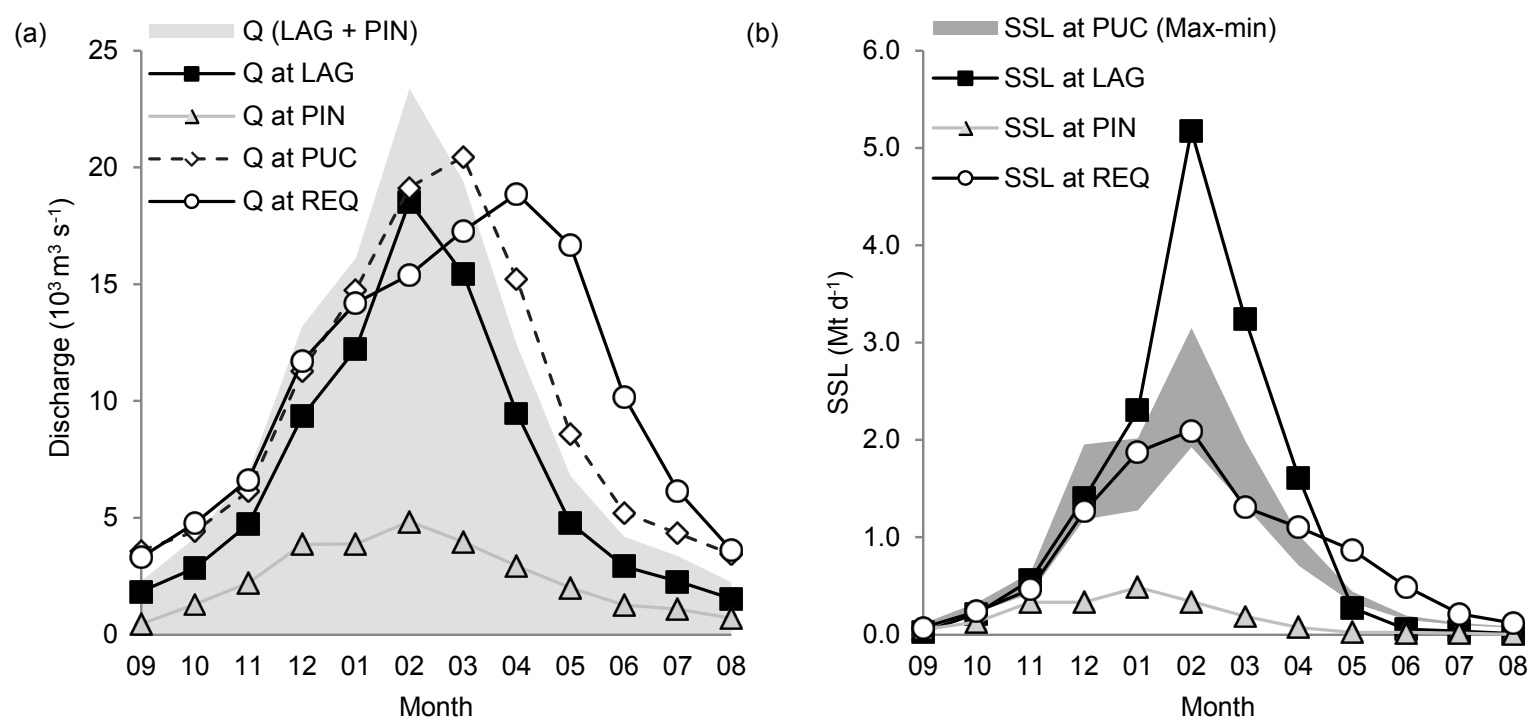

Fig. 2 (a) Mean discharge and (b) SSL of the Ucayali River during 2009-2012. Framed values at PUC due to the uncertainty of the remote-sensing methods applied here.

The difference in monthly SSL between LAG and PUC (Fig. 2(b)) indicates considerable sediment retention in the basin. Remote-sensing data make it possible to localize the main part of this sediment retention upstream of PUC, on the section lined and slope-controlled by the Shira Mountains thrust fault. This result differs from the findings reported by Armijos et al. (2013), which were based on a shorter sampling period that included the severe 2010 drought year, during which sediment remobilization between May and August probably masked a weaker sedimentation than other years between January and April. Furthermore, this first study did not considering lateral contributions.

The high specific runoff (Table 1) observed in the Pachitea basin can be explained by the presence of a hotspot of precipitation, but it could be also an indicator of the recent decline of 
vegetation in the upper basin due to anthropogenic activities. These two factors might explain the rapid denudation rate $\left(1.5 \mathrm{~mm}\right.$ year $\left.^{-1}\right)$ observed in this basin. This high denudation rate could also be linked with tectonic activity observed in this sub-Andean zone. The SSY calculated at LAG takes into account the whole Andean area of the basin. However, SSY spatial distribution is heterogeneous along the Andes, because of the different environmental conditions including climate, soil and topography. Since the early work of Ahnert (1970) associating the age of a mountain range and its denudation rates, numerous studies have contributed to the knowledge of the relation between tectonic, topography, lithology, climate, vegetation and erosion (Milliman \& Meade, 1983; Pinet \& Souriau, 1988; Milliman \& Syvitski, 1992; Summerfield \& Hulton, 1994; Dadson et al., 2003, 2004; Aalto et al., 2006; Syvitski \& Milliman, 2007; Pepin et al., 2013). All those works suggest a heterogeneous spatial distribution of the denudation rates in the Andean range due to the interaction between climate and orography, from north to south and from east to west. The east-west climatic gradient allows the development of a zone with increasing seasonality towards the east, probably at between 1000 and $4000 \mathrm{~m}$. a.s.l., that is favourable for erosion processes (Carretier el al., 2012), where vegetation declines and numerous small rivers incise. The eastern flanks of the cordillera concentrate the steepest slopes (Fig. 1) of the whole range and TRMM 3B42 v.7 rainfall data indicate the importance of the hotspot of precipitation by locating a quasi-continuous corridor of important rainfall between the Eastern cordillera and the sub Andean zone, from south Bolivia to north Ecuador. In contrast, the topography, lithology and climate of the central Andean range do not seem favourable for rapid erosion. For that reason, in the eastern part of the Ucayali Andean basin we can expect higher erosion rates than those calculated for the whole basin, probably closer to those observed in the Pachitea Andean basin.

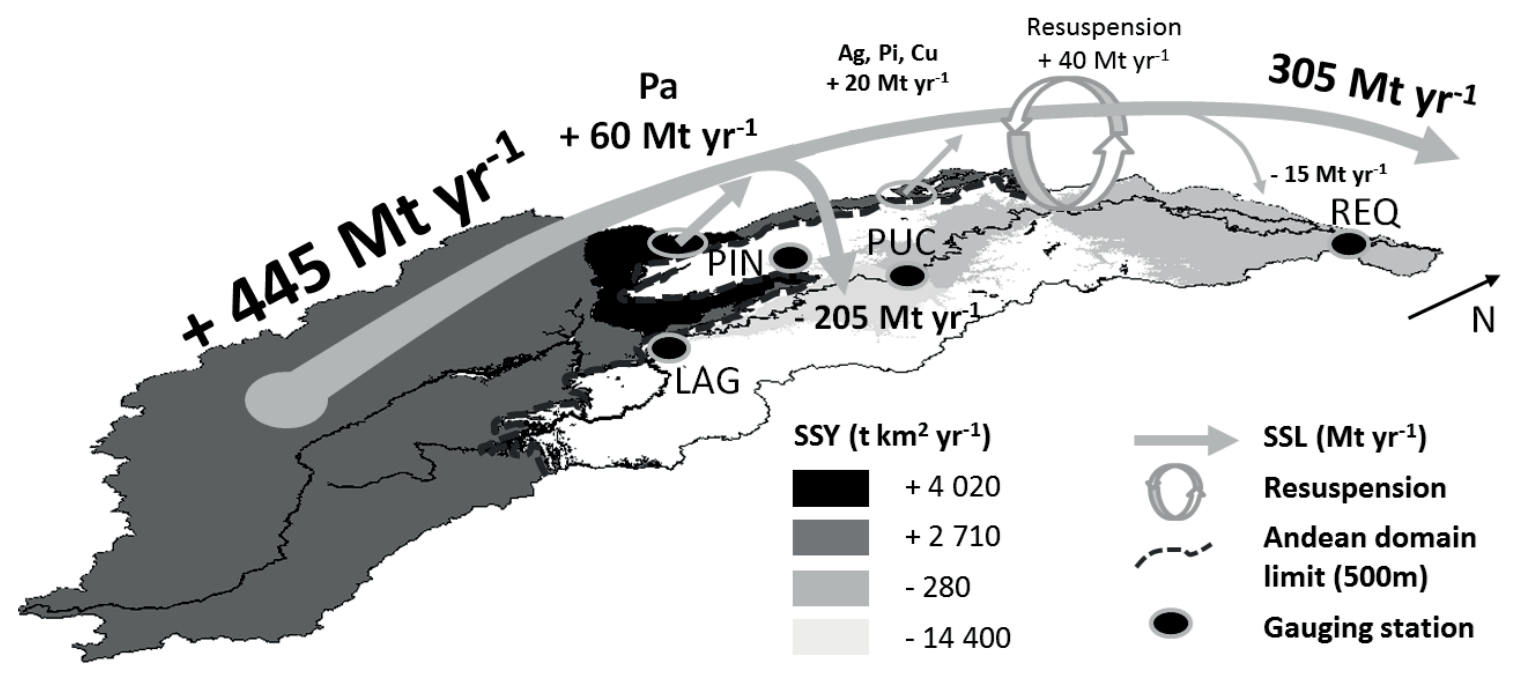

Fig. 3 Spatial distribution of SSY and the sediment budget in the Ucayali River basin.

\section{CONCLUSIONS}

Results presented in this study relate to the 2009-2012 hydrological period. The denudation rates assessed are among the most rapid of the whole Andean Amazon River Basin. For the first time, a considerable retention of sediment was found in the Ucayali River basin. A sediment flux of $525 \mathrm{Mt}$ year-1 is exported from the Andes in the Ucayali River floodplain, $220 \mathrm{Mt}^{-1} \mathrm{ear}^{-1}$ of which are deposited, mainly along the foreland lined by the Shira Mountains thrust system. Ucayali River sediment load represents about $36 \%$ of the Amazon River load delivered to the ocean. Resuspension of sediment previously trapped in the flood plain represents $13 \%$ of the total mass transported at the basin outlet. This information will be completed in the future with new data acquired within the HYBAM long-term monitoring programme. 


\section{REFERENCES}

Aalto, R., Dunne, T. \& Guyot, JL. (2006) Geomorphic controls on Andean denudation rates. The Journal of Geology 114, 85-99, doi: 10.1086/498101.

Ahnert, F. (1970) Functional relationships between denudation, relief and uplift in large, mid-latitude drainage basins. American Journal of Science 268, 243-263.

Armijos, E., et al. (2013) Suspended sediment dynamics in the Amazon River of Peru. Journal of South American Earth Sciences 44, 75-84, doi:10.1016/j.jsames.2012.09.002

Calmant, S., Seyler, F. \& Cretaux, JF. (2008) Monitoring continental surface waters by satellite altimetry. Survey in Geophysics 29, 247-269, doi: 10.1007/s10712-008-9051-1

Carretier, S., et al. (2012) Slope and climate variability control of erosion in the Andes of central Chile. Geology, 41(2), 195-198, doi:10.1130/G33735.1

Dadson, S., et al. (2003) Links between erosion, runoff variability and seismicity in the Taiwan orogen. Nature 426(6967), 648-651, doi:10.1038/nature02150

Dadson, S., et al. (2004) Earthquake-trigered increase in sediment delivery from an active mountain belt. Geology 32, 733-736.

Dumont, J.F., Deza, E. \& Garcia, F. (1991) Morphostructural provinces and neotectonics in theAmazonian lowlands of Peru. Journal of South American Earth Sciences 4, 373-381, doi:10.1016/0895-9811(91)90008-9

Espurt, N., et al. (2008) Paleozoic structural controls on shortening transfer in the SubAndean foreland thrust system, Ene and southern Ucayali basins, Peru. Tectonics 27(3), C3009, doi: 10.1029/2007TC002238.

Espinoza, J.C., et al. (2009) Spatio-temporal rainfall variability in the amazon basin countries (Brazil, Peru, Bolivia, Colombia and Ecuador). International Journal of Climatology 29, 1574-1594, doi:10.1002/joc.1791

Espinoza, J.C., et al. (2013) The major floods in the Amazonas River and tributaries (Western Amazon basin) during the $1970-$ 2012 period: A focus on the 2012 flood. Journal of Hydrometeorology 14, 1000-1008. doi:10.1175/jhm-d-12-0100.1

Espinoza-Villar, R., et al. (2012) The integration of field measurements and satellite observations to determine river solid loads in poorly monitored basins. Journal of Hydrology 444-445, 221-228, doi:10.1016/j.jhydrol.2012.04.024

Filizola, N.P. \& Guyot, JL. (2004) The use of Doppler technology for suspended sediment discharge determinations in the River Amazon. Hydrological Sciences Journal 49(1), 143-153.

Garreaud, R., et al. (2008) Present-day South American climate. Palaeogeography, Palaeoclimatology, Palaeoecology 281, 180-195, doi:10.1016/j.palaeo.2007.10.032

Guyot, J.L., et al. (2007) Suspended sediment yields in the Amazon basin of Peru: a first estimation. In: Water Quality and Sediment Behaviour of the Future: Predictions for the 21st Century (ed. by B.W. Webb, D. De Boer), 3-10. IAHS Publ. 314. IAHS Press, Wallingford, UK

Lavado-Casimiro, W.S., et al. (2013) Trends in rainfall and temperature in the Peruvian Amazon-Andes basin over the last 40 years (1965-2007). Hydrological Processes 27(20), 2944-2957, doi:10.1002/hyp.9418

Martinez, J.M., et al. (2009) Increase in suspended sediment discharge of the Amazon River assessed by monitoring network and satellite data. Catena 79, 257-264, doi:10.1016/j.catena.2009.05.011

Milliman, J.D. \& Meade, R.H. (1983) World-wide delivery of river sediments to the oceans. Journal of Geology 91, 1-21

Milliman, J.D. \& Syvitski, J.P.M., (1992) Geomorphic/tectonic control of sediment discharge to the ocean: the importance of small mountainous rivers. Journal of Geology 100(5), 525-544.

Pepin, E., et al. (2013) Climatic control on eastern Andean denudation rates (Central Cordillera from Ecuador to Bolivia), Journal of South American Earth Sciences 44, 85-93. doi:10.1016/j.jsames.2012.12.010

Pinet, P. \& Souriau, M. (1988) Continental erosion and large-scale relief. Tectonics 7(3), 563-582.

Summerfield, M. \& Hulton, N. (1994) Natural controls of fluvial denudation rates in major world drainage basins. Journal of Geophysical Research 99 (B7), 13871-13883.

Syvitski, J.P.M. \& Milliman, J.D. (2007) Geology, geography, and humans battle for dominance over the delivery of fluvial sediment to the Coastal Ocean. Journal of Geology 115 (1), 1-19.

Vauchel, P., (2007) Derniers développements du logiciel Hydraccess = Últimos avances del software Hydraccess. In: IRD : 30 ans en Equateur (ed. by P. Gondard, MD. Villamar), 247-251. IRD, Quito, Equateur. 